\title{
Speech act analysis of David Mamet's American Buffalo
}

\section{Firdaus Sleman Hamad}

College of languages-English deparment/Salahaddin university

firdasoloman@gmail.com

07507102420

Proff. Dr. Suhayla H. Majeed

suhaylamajeed@yahoo.com

07504628513

\section{ARTICLE INFO}

\section{Article History:}

Received: 25/6/2019

Accepted: 28/7/2019

Published: Fall /2019

DOI:

10.25212/lfu.qzj.4.4.41

Keywords:

Speech act theory

Pragmtics

taxonomy of speech

acts and drama

\begin{abstract}
Speech act is the usage of words and sentences that commits the speaker or the hearer to do something. Searle group's speech acts into five categories, which are assertives, directives, commisives, expressives and declarativies. This paper aims at analyzing the categories of speech acts in the play 'American buffalo' by david mamet.it aims to find the types and the functions of the speech acts and the difference between them.This is done through analyzing four texts of the characters' dialogues.through which we can understand the sophisticated personalities of the different characters. The analysis is carried out from a pragmatic point of view, mainly on the basis of the typology prposed by Searle (1969).
\end{abstract}

\section{Introduction:}

When people communicate, they rely on their language lexicon and the sets of linguistics rules. Most people are aware of the of language rules like the ones that determine the way in which linguistic elements as letters, words are combined together to form bigger constituents as phrases and clauses (syntactic knowledge), and also how words and larger structures have meanings(Semantics knowledge). However, communication between people is not a simple task and it requires serious collaboration from any parties involved in the conversation (Birner, 2012:1). In order to arrive at more than 
the meaning of what is said literally in communication; people need pragmatic knowledge alongside the semantic and syntactic knowledge.

Pragmatics became the topic of discussion in 1980s, but clearly, its definition has not been easy to decide on precisely, even after Morris (1938: 6) defined it "a branch of semiotics", and "the study of the relation of signs and interpreters". Some assume all language phenomenon that cannot be distinguished as syntax or semantics are pragmatics. The reason why pragmatics is hard to understand and formalize is that it deals with language and its users in a social context. A great number of authors and theorists including Grice (1957), Searle (1969), Petofi (1976), van Dijk (1976), Levinson (1983), Mey (1993), Martin (1994) and Yule (1996) have the common belief that pragmatics is the a study of 'natural language, that is how it is naturally used in real life conditions (Kaburise,2011:26).

Modern books have two distinct views on pragmatics; on the one hand, there are those that associate pragmatics with speaker meaning, and those who relate it with utterance interpretation. However, both of these views have their shortcomings, since those who equate pragmatics with speaker meaning focus more on the social aspect of language use and the role of the speaker and pay less attention to the fact that meaning can be interpreted on several levels. Those who define it as utterance interpretation; are more concerned with the cognitive aspect and focus more on the role of receivers of the message and ignoring the production of the utterance(Thomas,1995:2). One of the main concepts that pragmatics sheds light on is speech act theory.

\section{Speech Act Theory}

Speech act theory, also called "How to Do Things with Words Theory", is a philosophical approach to language, based on large scale on J.L. Austin's (1962) and John Searle's (1969) works. Bliss (1983) states that speech act theory, came about as a disagreement to the traditional philosophical approach which viewed sentences as detached from context and focused only on its truth conditions; i.e. their truth or falsity.

The very term 'speech act' was possibly, coined by the German linguist Buhler in 1934 Lyons (1977: 726). The theory as the name suggests deals with 
Speech Acts or as Levinson states (1991: 259) "action-like properties of utterances". Hurford and Heasley (1990: 239) define Speech acts as words or sentences that are employed to do things; which are of social importance and not to merely describe the world.

Speech-act theory, as used in the philosophical tradition, can be key for better comprehending language, since Speech-act theory is stronger than the prior tendency to think just in terms of separate propositional truths (Poythress,2008:16). Many philosophers considered the importance of the speech act theory fascinating, for a number of reasons. Lyons (1977:725) found the theory's importance in linguistics for its capability of giving "explicit recognition to the social or interpersonal dimension of language-behavior and provides a general framework". Van Dijk (1980) maintains that the philosophical and linguistic theory of speech acts is of great prominence among other basic concepts of pragmatics; and its concern has mainly been an abstract study of the illocutionary sides of language use. For Leech 1983 $(x)$, speech act theory's influence on pragmatics is estimated as the strongest stating "Up to now, the strongest influences on those developing a pragmatic paradigm have been the formulation of a view of meaning in terms of illocutionary force by Austin and Searle"

Despite its philosophical original, speech act theory eventually made its way into other areas of stud. It became applicable in linguistics, namely in syntax, in semantics, pragmatics, and even in sociolinguistics (Kock, 1997:14). Other areas where speech act theory sparked interest as Levinson $(1983,226)$ states include the field psycholinguistics where speech act theory is used as one of the necessary tools for language acquisition. It has also been taken up by literary critics to better understand the literary genres; anthropologists used it to find the magical spells and rituals in linguistics Levenson states that the theory has been applied to problems in syntax and semantics.

\subsection{Austin's Speech Act Theory}

Although in the sixties most of the focus and work of linguistics was mainly on syntax; within the framework of Chomsky's development of transformational grammar, there were few philosophers that worked on the semantics branch. It is believed that the theory was first foreshadowed by the Austrian philosopher Ludwig Wittgenstein's views in 1953; who claimed that the meaning of words is to be found in its use (Kock, 1997:3). However, Yuan 
(2007) argues that the theory itself is usually attributed to J. L. Austin. Austin went against the doctrine of logical positivism.

Austin's works triggered interest in what is now called pragmatics, although there were other famous philosophers as G. E. Moore and Wittgenstein during Austin's time; who also contributed to pragmatics. Austin's work was more influential due to four factors :firstly because the emergence of his collection lectures 'how to do things with words' was on time and in line with the growing disapproval of truth conditional semantics view. Second his work was comprehensible and thirdly despite the change and readjustment he made to his works, the main line of thought remained and finally his works indicates other important matters in pragmatics today(Thomas,1995:28).

On the basis of the concept that language is used to perform actions, Austin classified speech acts into constatives and performatives .Performatives are those utterances that change the state of the world somehow by performing a kind of action; not just to state something that can be either true or false. Constatives, however, are merely statements of fact, or declarative utterances expressing some state of affairs (Smith, 1991; Sadock, 2007).

Austin considered the acceptable convention and rules that follows for performatives to be successful, because although performatives cannot be true or false they could go wrong, be infelicitous or unhappy. These conditions for a speech act to be successful are called felicity conditions. Austin gave thses felicity conditions:

.A. (i) there must be a conventional procedure having a conventional effect

(ii) The circumstances and the persons be must be appropriate

B. the procedure must be executed (i) correctly (ii) completely

C. often(i)the persons must have requisite thoughts feelings and intentions as specified in the procedure (iii)if the consequent conduct is specified, then .the relevant parties must do it (Levinson, 1983:229)

Austin also made a three-folded contrast between three types of acts that occur when language is used, they are characteristics of most performative and constatives too (Horn and ward, 2004):

1. Locutionary Act: Austin $(1962,108)$ states locutionary act is the uttering of a specific sentence with sense and reference. 
2. Illocutionary Act: This type of act is related to speakers' intentions and motives i.e. asserting, questioning, warning, requesting, and giving commands, threatening.

3. Perlocutionary act: This type of act deals with what is gained by the performance of a speech act. While the illocutionary act is speaker concerned, the perlocutionary act is hearer based; just as the illocutionary acts have illocutionary force, perlocutionary acts has a perlocutionary effect on the hearer (Birner, 2012:187).

In addition, Austin (1962:151) sat up five categories of speech act based on illocutionary force as folwws:

1. Verdictives: They are acts in which a verdict or appraisal is given, usually by someone in a position of power to give that appraisal.

2. Exercitives They involve the exercise "of powers, rights, or influence."

3.Commissives They commit the speaker to an action or intention.

4.Behabitives These acts have to do with social behavior, including "apologizing, congratulating, commending etc.

5. Expositives These are acts that plain how our utterances fit into the course of an argument or conversation, how people are using words, or, in general, are expository.

Many scholars in also contributed to the development of speech act theory after Austin such as Strawson (1964); Grice (1967); Searle (1969, 1976); Benjamin (1976); Davison, Wachtel, Spielman, etc. (1971) (Kock,1997:3). John Searle, a major proponent of the speech act theory, inherits his ideas from Austin and elaborates on some of them but develops the theory in his own style.

\subsection{Searle's Account of Speech Act Theory}

Although Austin's theory was taken for further elaboration by several theorists most importantly by Searle, Zaefferer (2001) states that Searle's formalized Speech Act theory has become something classic, at least among the majority of linguists. He adds although his five-fold classification has been criticized many times; alternatives have been proposed, nonetheless; until this day, it continues to be the most widely accepted one. 
Searle's development of Austin's work comes mainly from his most important works namely Searle $(1969,1979)$ and Searle and Vanderveken (1985) .Searle's works in (1969-1979) started where Austin's had finished off; and his earlier works had focused on trying to put Austin's ideas into a unified and systemized theory through a number of contributions (Smith,1991:3).

Unlike the precedent studies of language that have considered words, sentences, morphemes etc. as the basis of investigation, Searle suggests that language should have been studied with reference not to linguistic types or tokens, but with reference to certain actions; i.e. illocutionary acts (Doerge, 2006:72). In other words, the assumption of his speech act theory is that the minimal unit of human communication is not sentences but performing illocutionary acts as suggesting, commanding, requesting etc. (Searle, Kiefer and Biervich, 1980:5).

Searle's perspective was somewhat different from Austin's, since he did not approve of Austin's distinction made between locutionary, illocutionary and perlocutionary acts. He does not disagree with perlocutionary and illocutionary act, but divides locutionary acts into two other types of acts namely utterance act and propositional act.

Sealer's focus was mainly on the description of illocutionary acts, but he does not give a straight and forward definition of speech acts, the closest definition is that they are the basic or smallest unit of all linguistic communication Searle(1969, 16) .Instead he(1969:24) describes them by listing the subtypes of speech acts:

(A) An utterance act by uttering words, morphemes, or sentences.

(b) A propositional act (by referring and predicating),

(c) An illocutionary act (by questioning, stating, requesting, etc.),

(d) A perlocutionary act (by achieving some effect on the actions, thoughts, etc. of his/her hearer).

These acts are performed in accordance with rules (Searle, 1969: 16, $24-25,37)$ they are not separated but happen at once. When one preforms an illocutionary act, he also performs a propositional act and an utterance act. A distinction was also made between propositional and illocutionary acts, for instance the following examples have the same propositional act but have different illocutionary acts: 
1. Sam smokes habitually.

2. Does Sam smoke habitually?

3. Sam, smoke habitually!

4. would that Sam smoked habitually! (Searle1969:22-24)

Since all of these examples refer to the same person 'Sam' and all of them have the same proposition (content) which is 'Sam smokes habitually' all of the sentences perform the same propositional act (Tiesma, 1986). However, in each of these utterances, the speaker has a different intention (force or function), that is in 1) the speaker performs an assertion, 2) is a questions, 3 ) is an order, in 4) is a type of wishfully s request. The reference and the predication appear in different places in each utterance and in each utterance, a different speech act is attempted.

Searle also tackles some other notions such as rules, propositions and meaning. The rules of a language give meaning to sentences and help the speakers to send messages, which are in return understood by hearers. He argues1969 $(36-7,41)$ that "speaking a language is engaging in a rulegoverned form of behavior" and "performing acts according to rules". Searle called such rules constitutive rules, which usually make up part of the activity and cannot be separated from it. For example, in the rules of the game of chess the rules are constative of the game itself (Schiffrin,2005:44).Searle contrasted the constitutive rules with regulative rules which "regulate our linguistic behavior", Regulative rules are those that regulate activities that are already in use(Fotion,200:23). For example a car can still be driven without abiding by traffic regulations, but it is not possible to drive it without starting the he engine, pressing in the clutch, etc(Schiffrin,2005:45).

When it comes to the notion of Meaning, Searle tries to answer questions like what is it to say something and mean something ? and what does it mean for something to have meaning? Attempting to answer such question, he borrows Grice's definition of the term 'meaning' that states : "To say that a speaker meant something by $X$ is to say that he/she intended the utterance of $X$ to produce some effect in hearer by means of the recognition of this intention" (1969: 43). However, Searle considers such notion to be defective since it does not show the connection between ones meaning of something and how it actually means. 
Searle and Vanderveken (1985:53) also introduce a language feature which is direction of fit arguing that there are "four and only four" possible directions of fit for any utterance. Here is their account of direction of fit:

1. The word-to-world direction of fit: In achieving success of fit, the propositional content of the illocution fits an independently existing state of affairs in the world.

2. The world-to-word direction of fit: In achieving success of fit, the world is altered to fit the propositional content of the illocution.

3. The double direction of fit: In achieving success of fit, the world is altered to fit the propositional content by representing the world as being so altered. 4. The null or empty direction of fit: There is no question of achieving success of fit between the propositional content and the world, because in general success of fit is presupposed by the utterance.

\subsubsection{Searle's felicity conditions:}

Guided by constitutive and regulative rules of language use, Searle (1969) also suggests felicitous conditions that are different from the ones proposed by Austin. Searle's felicity conditions are not dimensions on which utterances can be successful or unsuccessful rather they are "constitutive of the various illocutionary acts". The conditions that Searle outlined are the following (1969: 54-71) :

1. Propositional content conditions: These refer to the constraints put on the content by the performance of a felicitous illocutionary act such as tense or subject of utterances. For instance in the case of promises, the content must refer to a future action; it is not possible to say 'I promise to have done it by last week' (Schifrin, 2005:48).

2. Preparatory conditions: These are the presuppositions that is made about the illocutionary act, which is usually "peculiar to illocutionary force". For instance, when the speaker promises something, it usually presupposes that he/she is able to fulfil that promise.

3. Sincerityconditions: these conditions indicate that the speech act performed is in line with what the speaker believes, intendeds or feels, for 
example the speaker intends to fulfil his promise or believes what he/she asserts.

4. Essential conditions. Searle explains this condition in terms of intention since speech acts are preformed intentionally. Fotion (2000) states that this condition deals with what 'counts as' for instance 'request' counts as an attempt to make addressee to perform an action, a 'promise' counts as putting an obligation on the speaker to do an action, etc.

\subsubsection{Searles Taxonomy of Speech Acts}

Searle criticizes Austin's taxonomy in that there is a widespread confusion between verbs and acts, and that not all the verbs are illocutionary verbs, the categories overlap too much, and there is much diversity within the categories. Many of the verbs listed in the categories also do not match the definition given for the category and, most prominent defect is that there is no consistent principle of classification (1979:11-12).

Searle taking into consideration four basic dimensions: illocutionary point, propositional content and its direction of fit and expressed sincerity conditions, as the basis for constructing his alternative classification that are roughly five groups, Searle (1975: 356-364) presents them as follows:

\section{Assertive:}

Members of this class are assertions that represent the state of affairs. The point or the purpose in performing Assertives is to commit the speaker to the belief or to the expressed propositional content. All of the members can be evaluated in terms of truth or falsity.

\section{Directives:}

The illocutionary point of members of this category are attempts by the speaker to make the hearer do something. The attempts can vary in strength they could be mild, or strong. The direction of fit is world to word the sincerity condition is wanting (or wish or desire).

\section{Commisives:}

Commisives are illocutionary acts whose point is to make the speaker responsible for some future action. The direction of fit is world-to-word and the sincerity condition is intention. The propositional content is again usually that the speaker does some future action.

\section{Expressives:}

The speech acts whose illocutionary point is demonstrate the speaker's psychological state to some former action or state of affairs. 
Expressive verbs are thanking, congratulating, apologizing, condoling, deploring, and welcoming. Expressives lack direction of fit. This means that performing an expressive, the speaker is neither trying to get the world to match the words nor the words to match, the world, rather the truth of the expressed proposition is presupposed.

\section{Declaratives:}

These are acts when performed successfully they bring into being a state of affairs, creating immediate changes in the world when the speaker utters such acts thus creates a correspondence between the propositional content and the world.

Thus, Searle's five classes can be shortly summarized as:

1) "Tell people how things are",

2) "Try to get them to do things",

3) "Commit ourselves to doing things",

4) "Express our feelings and attitudes",

5)"Bring about changes through our utterances" (Ballmer and Brennenstuhl, 1981:56).

The following are examples of the corresponding five types of speech acts (Huang, 2006:106-108):

The soldiers are struggling on through the snow.

Turn the TV down.

I will be back in five minutes.

Example

I'm so happy.

We find the defendant not guilty.

-Below is Searle's classification of the acts in accordance with direction of fit and the role of the speaker:

\begin{tabular}{|l|l|l|l|}
\hline NO & Speech act type & Direction of fit & Speaker's role \\
\hline 1 & Assertives & Words fit the world & Speaker believes X \\
\hline 2 & Directives & World fit the words & Speaker wants X \\
\hline 3 & Commisives & World fit the words & Speaker intends X \\
\hline 4 & Expressives & Words fit the world & Speaker feels X \\
\hline 5 & Declaratives & Words change the world & --------------- \\
\hline
\end{tabular}


Table (1) of Searle's classification of illocutionary acts (Al-Sulaiman, 2011:293)

\subsection{Speech Act Theory and Drama}

At first, it was usual for the speech act theory to be applied to language exclusively; later it gradually became more common practice for its application on literature genre. Pratt (1997) admits that the first attempt for the application of speech act theory on literature was made by Ohman 1971.Pratt's views are different from Ohman's. Ohman's belief is that since not all of Austin's felicity conditions can be applied to statements within works of literature, and ordinary language differs from literary language, therefore they should be called "quasi speech acts". Pratt especially in Traugott and Pratt (1980) disagrees with Ohman. Following Partt, many researchers applied speech act theory to different genres of literature. (Abbas, 2011:14)

Koten (2012:174) states, "Literature cannot imitate reality directly, it can perfectly imitate an utterance about reality". Thus, a fictional utterance might have form of assertion even if it is not actually an assertion itself. Accordingly; authors of fictions can get special effect; although, readers of fiction know about fictitiousness of a speech act, they read the fictional story as if it was real. So, when readers read a novel, or a drama they could in their imagination treat the circumstances as if they were real.

According to Thornborrow and Wareing (1998) since plays exist in two forms i.e. as text and on stage; there has been some issues for researchers and they require different approaches. Some critics believe that since plays are written for performance on stage, they can be understood only in theater. Others have found it easier to focus on the written texts than its performed version when analyzing; since the language of plays consists of turns or dialogues among characters of the text. In addition, linguistic analysis of drama can show that plays contain very rich instruction for their performance which Searle (1975:328) states are "directions given by the writer of the play for the actors" as to how to enact a pretense, which the actors then follow.

Therefore, understandings of plays can be accomplished through 'mere reading" (Meek and Short, 2007:7).

Austin (1962:22) in his speech act theory, excluded literature and drama in his analysis stating, "performative utterance will fail if uttered on stage by an actor and further adding speech acts used in literary works are "void". Later, he acknowledged that the dramatic communication happens through a language that looks like real world conversations. 
Bliss (1983:16) states that Speech act theory has been used to define fiction itself and to tackle certain literary texts. It has especially been beneficial to viewing texts as a communicative act and not just merely as only in and of itself. Speech Act Theory of literature in its entire genre, highly values the context in which it is uttered. Speech Act theory is highly noticeable in bringing together language and literary thoughts and goals, the set of concepts included in Speech Act Theory are applicable to the different kinds of literary works as novel, drama, poetry, and so on.

According to Brown and Levinson (1987, 1987:10) since Speech Acts, analysis is a sentence-based, speaker-oriented type of analysis; it could provide a lot of information when applied to a speaker-oriented genre like plays. A character's ability to use performative language is often an indicator of how much power s/he has in the play. Many critics have analyzed Renaissance drama holding such views particularly tragedies.

Van Dijk (1977:5) argues, "literature constitutes a speech act on its own." because a literary text generally is made of multiple sentences and such sentences can be taken as a possible speech act. Koten (2012:175) states that the character's interactions in a play imitate authentic speech acts, such as assertions, warnings, promises, requests, orders, verbal expressions of states of mind and emotions.

\subsection{Mamet's Language}

David Alan Mamet Born in 1947 is the son of a labor lawyer and the product of a painfully broken home (The Independent, 2008). David Mamet is considered, one of the most well known American playwrights of his generation along with Sam Shepard. His most incredible five important plays now considered famous are Sexual Perversity in Chicago (1974), followed by American Buffalo (1975), Edmond (1982), Glengarry Glen Ross (1983), and Oleanna (1992). All of them were produced in theatres internationally. He has won many awards as Joseph Jefferson Award, the Obie Award, and New York.

Drama Critics Circle Award, Outer Circle Award, Society of West End Theatre Award, Pulitzer Prize, Dramatists Guild Hall-Warriner Award, and the Tony Award For his interesting works since 1974 .In addition to many awards winning films, his works for stage and screen nominations are plenty. Many academic studies have also paid attention to Mamet as a dramatist and the aesthetic/linguistic strategies he uses within the context of theatre and drama 
history. Both Christopher Bigsby1985; who is an important scholar of modern American drama and Dennis Carroll 1987 conducted studies of Mamet's' work (Collard, 2015).

Mamet's drama discourse is usually infamous for informal discourse and usage of slang as a way of expression of strong feelings. Some critics compared him to Eugene O'Neill, especially in his skill to make believable the speech patterns of usual street life. Although some critics believe there isn't much action in his plays; all speech in Mamet's plays are sort of action or speech acts; i.e. characters in his plays usually admit, deny, offer, accept, deceive, sell, plead, reveal, and conceal using language. In this fashion, Mamet more than any contemporary playwrights tries to convey actions through the characters dialogue using language (ibid).

Wahtely (2011) argues that Mamet's language of writing is both minimalist and poetic. His language is considered minimalist in the sense that Mamet usually uses very few words to convey the message and poetic in the sense that he is able to add poetic rhythm to normal street conversation, which is characterized with much profanities, slurs, and insults.

Mamet is famous for writing two types of plays: the social/urban plays, which usually happens in a business-like environment; where the characters are in constant competition with one another; the second type is the domestic/rural play, which is usually set in the outer setting or home and is concerned with persons trying to communicate by meaningful communication. Accordingly, some refer to the language of social/urban plays as realist and the domestics/rural as poetic (whately, 2011:19).

American buffalo is his two-act play that revolves around three characters namely Don, Teach a Bob. The first act occurs in "Don's Resale Shop," which is a junk store run by Don Dubrow who is the play's protagonist. The second act occurs at 11:15 that evening and Teach has not yet arrived. Don is also unable to reach Fletcher, whose phone line is busy as well.

\subsection{Methodology:}

This study relied on a descriptive qualitative method to analyze the speech acts. The data were in the form of utterances taken from the play. The source of the data was the script David Mamet's play. The analysis of the play 
is carried out using Searle's five typology of speech acts, which are applied to the speech acts identified from the speech of the three main characters.

\subsection{Data analysis:}

\subsubsection{Analysis of Assertive Speech Acts}

The first analysis will be of the class of the Assertives which are the first group distinguished by Searle.

According to Searle's theory of speech acts; the category of Assertives have the illocutionary point or purpose to commit the speaker to the truth of the expressed proposition to something he believes to be the case or not (Searle 1979: 2). Assertive speech acts express the speaker's belief and his intention or desire that the hearer form similar belief. An utterance that asserts a thing that can be judged as true or false. The illocutionary point of an assertive act focuses on persuading the hearer to form a parallel belief. The mode of achievement and the propositional content condition are neutral.

The preparatory condition is that the speaker has reasons or proof for the truth of the propositional content. The sincerity condition is that the speaker believes the propositional content. The degree of strength is neutral. This group contains most of Austin's (1962) expositive and many of his verdictives, e.g. suggest, put forward as a hypothesis, insist, swear, stating etc.

\section{Text (1)}

Don: and he's no dummy, Teach

Teach: far from it. all I'm saying, the job is beyond him. Where's the shame in this? This is not jacks, we get up to go home we give everything back. huh? you want this fucked up?

Pause

All I'm saying, there's at least chance something might fuck up, you'd get the law down, you would take the shot, and couldn't find the coins whatever: if you see the least chance you can't afford to take the chance! Don? I want to get in there and get thus motherfucker. Don? where I the shame in this?

\section{Context:}

Teach and Don are at the shop talking about Bobby and whether to send him in for the business or not.

\section{Discussion:}

Don has decided to include Bob in the business which is sending him to steal back the nickel from the man who bought it with a low price from Don's 
store the previous day. This decision does not appeal to Teach very well; therefore, he explains lengthily to Don that Bob is not qualified enough for the mission and that he might have his own hidden motive. Instead he wants to go for the stealing. Teach first states that "the job is beyond him" which expresses his proposition of Bobby not being incompetent for the robbery. In uttering such sentence, he aims to create a similar belief on Don. Following Searle an assertive act is one that asserts something which can be judged as true or false and focuses on forming a parallel belief on the hearer. Therefore, Teache's utterance counts as an assertive act that has the function of a persuasion. Later he says "All I'm saying, there's at least chance something might fuck up"; this utterance has the proposition that counts as a prediction to some future action. Teach predicts some possible bad future action might occur if Bob went in instead of him. Teache's second utterance counts as an assertive act here functions as prediction.

\subsubsection{Analysis of Directives}

The second type of the analysis in the play is directives as it complies with Searle's second class in his taxonomy of speech acts:

They are speech acts by which the speaker asks the hearer(s) to do or not to do things. The speaker[s] perform directives with the intention of committing the hearer to a future action, usually to make the world fit the words through the hearer (Jucker and Taavitsainen, 2008), 2008:88). The speech acts that are listed in this group by J R Searle (1969) include requesting, questioning, ordering, commanding, suggesting, urging, inviting etc. . The class also includes many of Austin's exercitives are also in this class.

According to Searle and Vanderveken (1985:55) directives in general have the propositional content condition of some future action of the hearer. They also have the preparatory condition that the hearer is able both physically and mentally to carry out the action he needs to do. Therefore, directives in general have the sincerity condition that the speaker wishes/wants something from the hearer with varying degrees of strength according to their illocutionary forces. Lastly, directives usually make a reason of why the hearer does the something he is directed to. They can be realized by imperatives and subjunctives. Furthermore, indirect requests can be expressed by interrogatives and declaratives (Jucker and Taavitsainen, 2008), 
2008:88). In addition, they can be used for quite a number of illocutionary acts, ranging from order or command to plea, advice, offer, suggestion and wish. The propositional content is always indicated by hearer's some future action.

\section{Text (2)}

Don: well, that very well maybe. Bob, but the fact remains that it was business. that is what business is.

Bob: what?

Don: people taking care of themselves

Bob: no

Don: because there is business and there is friendship. Bobby there are many things, and when you walk around you hear a lot of things and what you got to do is keep clear who your friends are, and who treated you like what.

\section{Context:}

Don and Bob talk about Ruthie and Fletcher. Fletcher bought off an object that Ruthie owned, he got it with a really low price which led Bob to think it is stealing.

\section{Discussion:}

The dialogue above occurs between Don and Bob, Don is instructing Bob about the importance of business and the difference between friendship and business. Bob reveals to Don that Fletcher stole a pig iron(an object) from Ruthie despite them being friends with one another, in reality Fletcher cheated Ruthie and bought it really inexpensively. This leads Bob to consider such act same as stealing. Don, however considers what Fletcher did a business and nit staling. He assumes that this is the way people care for themselves. As wrong as it may sound, he advices Bob to follow the same pattern. He advices Bob that what he should do is distinguishing between business and friendship. His sentence "you got to do is keep clear who your friends are" has a directive meaning because it contains the phrase 'got to' therefore functions as an advice. Searle (1979) lists advising as a directive speech act, because the point of directives is urging the hearer to do some sort of action. Accordingly, Bob is advised by Don is urged to be aware of telling apart friendship and business and recognizing his true friend. Dons 
utterance is a directive speech act with the illocutionary force (function) of advice.

\subsubsection{Analysis of Commisives:}

The last part of the analysis is Commisives that are the fourth group in Searle's taxonomy:

According to Searle (1979), these are speech acts that their successful performance commits and puts the speaker under the obligation to bringing about the truth of the expressed propositional content. Hancher (1979) states that although Searle dose not talk about the variation in the degrees of commitment, they do here vary in somehow, as in the difference between carrying out something through promising or guaranteeing.Radhi( 2017) states that this category includes different verbs such as offer, promise, refusal, pledge, threat, vow, swear, acceptance. According to Vanderveken and Kubo (2001: 34) and Mey (1993: 164) the speaker is the one that usually carries out the future action by which the world is made to match the expressed proposition of the utterance.

\section{Text (3)}

Teach: I want for you to tell us here and now (and for your own protection) what is going own, what is set up where Fletcher is and everything you know. Don: I can't believe this

Bob: I Don't know anything

Teach: you Don't?

Bob: no

Don: tell him what you know, Bob

Bob: I Don't know it, Donny. Grace and Ruthie

Teach grabs a nearby object and hits Bob viciously on the side of the head.

Teach: grace and Ruthie up your ass, you shit head; you Don't fuck with us, ill kick your fucking head in (come in here with your fucking stories)

\section{Context:}

Don and Teach are outside at midnight waiting for Fletcher to come; instead, Bob shows up and is being secretive and Teach is not taking it well.

\section{Discussion:}

Don and Teach intend to carry out the robbery alone nut to their surprise Bob comes back to where Don and Teach are waiting for Fletcher. Bob is behaving suspiciously; Don and Teach come to the conclusion that he 
is hiding something from them which makes Teach particularly angry. Teach is indirectly threatening Bob that he will hurt him; if does not cooperate when he states "for your protection". According to Searle, (1969) the speech act of threatening is also considered a commissive speech act, whose illocutionary point or purpose is to express a future penalty for the hearer under a certain condition. So as to encourage the hearer not to make that condition true .When Bob didn't do as told, Teach indeed committed himself to the act of doing harm to Bob as it's clear that he hit Bob on his head when Bob didn't cooperate with them. Teach preformed a commissive act, which functions as threat.

\subsubsection{Analysis of Expressives:}

The third group that is analyzed are expressives, they are the third class of Searle's proposed taxonomy of speech acts:

They refer to the expressed feeling of the speaker either about themselves or about the world (Searle 1976: 12). i.e. Expressive speech act verbs usually are there to express good or bad evaluations, and they are hearer-oriented Examples of expressive speech act verbs are e.g. apologizing, consoling, congratulating, lament, praise, greet or welcome (ibid.). In performing expressives the speaker is neither trying to get the world to match the words nor the words to match, the world, rather the truth of the expressed proposition is presupposed(Searle,1975:256-657).

\section{Text (4)}

Teach: and tell him he shouldn't say anything to Ruthie

Don: he wouldn't

Teach: no? No, your right.im sorry, Bob.

Bob: it's okay

Teach: I'm upset

Bob: its okay, Teach.

Pause

Teach: thank you.

Bob: you're welcome.

\section{Context:}

Don, Bob, and Teach are at the store, Don wants to send Bob to fetch some breakfast, Teach says something to Bob to which he soon apologizes. 


\section{Discussion:}

In the above exchange of speech between Don, Bob, and Teach, Teach thinks if Bob goes to the diner to get food for him and Don, he might inform Ruthie about Teache's place. He doesn't directly say to Bob not to say he is at Dons shop, but asks Don to tell Bob. Although Don affirms that Bobby wouldn't, he is suspicious; thus stating jokingly asks "he wouldn't?. Then realizing that what he said was wrong he expresses his regret and apologizes to Bob. Searle and Vanderveken (1985:16) state that usually a speaker apologizes for something he/she did or feels responsible for doing. Teach realizes what he said was insulting to Bob thereof he felt the responsibility to apologize followed by the excuse that it was his anger led him to do so. Bob accepts his apology and Teach shows his gratitude by thanking him. Following Searle (1969:65) thanking is an act performed by the speaker in response to a past act conducted by the hearer which is usually in hearers favor. It can be said that both of Teache's utterances carry out the execution of the expressive speech acts; his first utterance functions as an apology and his second functions as thanking

\subsubsection{Analysis of Declarative:}

These are acts when performed successfully they bring into being a state of affairs, creating immediate changes in the world when the speaker utters such acts thus creates a correspondence between the propositional content and the world. Because most of them need extra linguistics institution for their performance, they sometimes are referred to as "institutionalized performatives" (Huan, 2006:108). Their successful performance brings about a fit, therefore the direction of fit is both words-toworld and world-to words. There is no sincerity condition

It is worth mentioning only the four categories of searle's taxonomy could be found in the play; .examples of the category of decalartives were not found.

\subsection{Conclusions:}

Based on the previous data analysis, it can be concluded that there are different forms and functions of the speech acts that are employed by the 
characters. Uually the speech acts fluctuated depending on the characters attitudes and their psychological states.In general the context and the nature of the relationship between the characters plays a prominent role in choosing a specific form of an act. In most cases the speech acts were performed successfully in the sense that the speaker usually carried out the act as in text(3) where the perlocutionary act is clear when the harm was actually done to the hearaer. Some of the acts were used indirectly depending on the condition.The first four categories of the speech acts namely" Assertives, directives, Commisives, expressives were frequently found in the play with different forms and function. Acts that belonged to declaratives the fifth category nonetheless were not found at all in the play.

\section{Bibiliography:}

1. Al-Sulaimaan, M. M. D. (2011): Semantics and Pragmatics, Mosul: Daar Ibn AL - Atheer Li AL - Tibaa'ti Wa Al - Nashr.

2. Austin, J. (1962). How to Do Things with Words, 2nd ed. Cambridge, Mass.: Harvard University Press

3. Ballmer, T. and Brennenstuhl, W. (1981). Speech act classification. Berlin: Springer-Verlag.

4. Birner, B. (2013). Introduction to pragmatics. Chichester: Wiley-Blackwell. 5. Bliss, C., 1983. Writing as Action: Using Speech Act Theory in the Composition Classroom.

6. Brown, P., Levinson, S.C. and Levinson, S.C., 1987. Politeness: Some universals in language usage (Vol. 4). Cambridge university press.

7. Dörge, F.C., 2006. Illocutionary acts: Austin's account and what Searle made out of it.

8. Fotion, N. (2014). John Searle. Abingdon, Oxon: Routledge.

9. Jucker and Taavitsainen, 2008), A. and Taavitsainen, I. (2008). Speech acts in the history of English. Amsterdam: John Benjamins Pub. Co.

10. Hancher, M., 1979. The classification of cooperative illocutionary acts. Language in society, 8(1), pp.1-14

11. Horn, L.R. and Gregory Ward (eds.) (2006). The Handbook of Pragmatics. Oxford: Blackwell Publishing Ltd 
12. Huang, Y. (2007). Pragmatics. New York: Oxford University Press

13. Hurford, J. and Heasley, B. (1990). Semantics. [online] Google Books. Available at:

https://books.google.com/books/about/Semantics.html?id=WZVr3ctwYsOC [Accessed 22 Jan. 2019].

14. Kaburise, P. (2011). Speech Act Theory and Communication: A Univen Study. [ebook] Newcastle: Cambridge Scholars Publishing. Available at: https://books.google.iq/books? [Accessed 17 Jan. 2019].

15. Kock, L.J., 1997. The drama of Senkatana by SM Mofokeng: a speech act exploration (Doctoral dissertation).

16. Leech, G. (1983). Principles of Pragmatics. London: Longman Group Ltd.

17.Leech, G. and Short, M. (2007). Style in fiction. Harlow: Pearson Longman.

18. Levinson, S. C. (1983): Pragmatics. Cambridge: Cambridge University Press.

19.Lyons, J. (1977). Semantics. Cambridge: Cambridge University Press.

20. Mey, J. L. (1993). Pragmatics: An Introduction. Oxford: Basil Blackwell Ltd.

21. Poythress, V.S., 2008. Canon and speech act: limitations in speech-act theory, with implications for a putative theory of canonical speech acts. Westminster Theological Journal, 70, pp.337-354

22. Sadock, J., 2004. Speech acts. Handbook of pragmatics, pp.53-73.

23 Sbisà, M. (1994): "Language and Dialogue in the Framework of the Analytic Philosophy of Ordinary Language. In Weigand, E (ed.), Concepts of Dialogue, pp. 159-169Searle, J. R. (1969): Speech Act Theory, Cambridge: Cambridge University Press.

24. Schiffman, H. (n.d.). Speech Acts and Conversation. [Online] Sas.upenn.edu. Available at: https://www.sas.upenn.edu/ haroldfs/edling/handouts/speechacts/spchax2 .html [Accessed 29 Feb. 2019].

25. Schiffrin, A., 2005. Modelling speech acts in conversational discourse (Doctoral dissertation, Un1iversity of Leeds

26. Searle, J. (1969). Speech acts: an essay in the philosophy of language. London: Cambridge U.P. 
27. Searle, J.R., 1975. A taxonomy of illocutionary acts

28. Searle, J. R. (1979). Expression and Meaning: Studies in the Theory of Speech Acts. New York: Cambridge University Press

29. Searle, John R., Ferenc Kiefer, and Manfred Bierwisch, eds. Speech act theory and pragmatics. Vol. 10. Dordrecht: D. Reidel, 1980.

30. Searle, J. R. and Vanderveken, D. (1985): Foundations of the Illocutionary Logic, Cambridge: Cambridge University Press.

31. Smith, P.W.H., 1991. Speech act theory, discourse structure and indirect speech (Doctoral dissertation, University of Leeds).

32. Tiersma, P.M., 1986. The language of offer and acceptance: Speech acts and the question of intent. Calif. L. Rev., 74, p.189.

33. Thomas, J. (1995). Meaning in Interaction: An Introduction to Pragmatics. London: Longman Group Limited.

34. Verschueren, J., 2008. Context and structure in a theory of pragmatics. Studies in Pragmatics, 10, pp.13-23.

35. Yule, G. (2010). The study of language. 4th ed. Cambridge University Press. 36. Zaefferer, D., 2001. Deconstructing a classical classification: A typological look at Searle's concept of illocution type. Revue internationale de philosophie, (2), pp.209-225

\section{بـوختـه:}

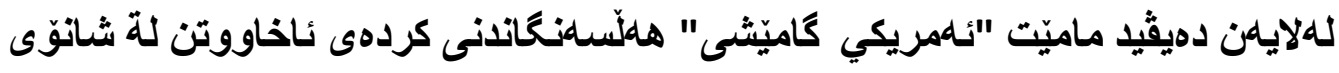

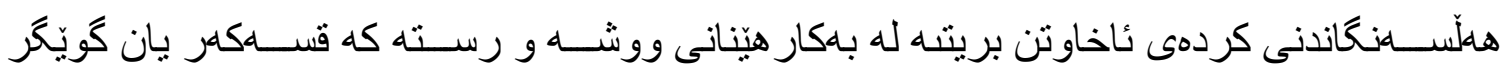

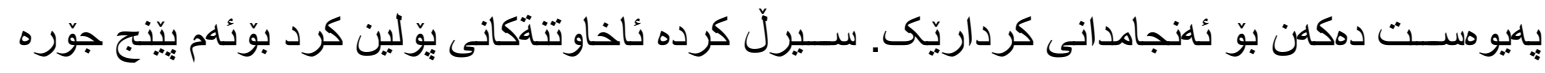

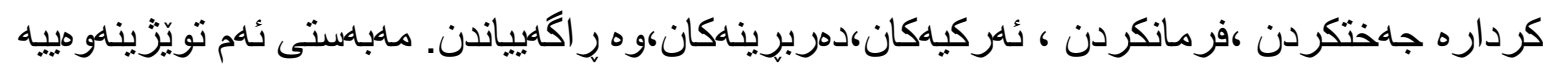

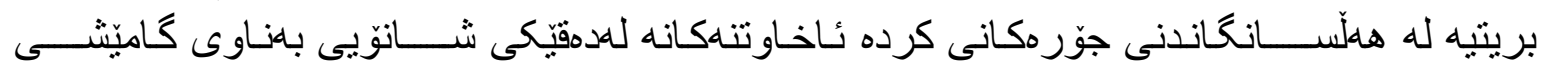

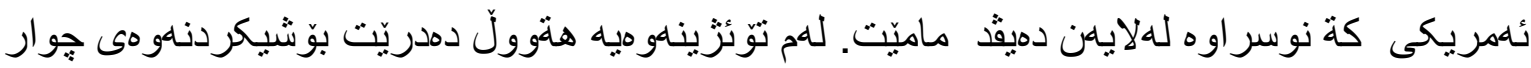

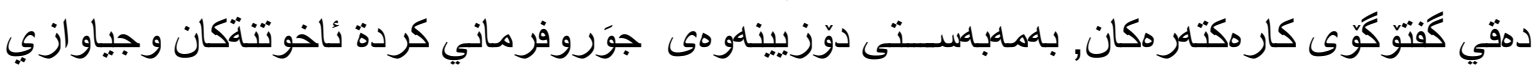




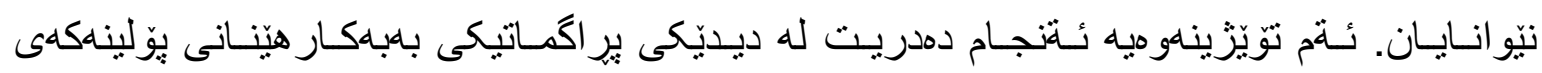
سيرل(1969). مخلص: تحليل الفعل الكلامي في مسرحية" الجامووس الأمريكي" من قبل ديفد مامي

الفعل الكلامي هو استخدام الكلمات والجمل التي تلزم المتكلم او المستمع لفعل شئ. يسرد سيرل أعمال

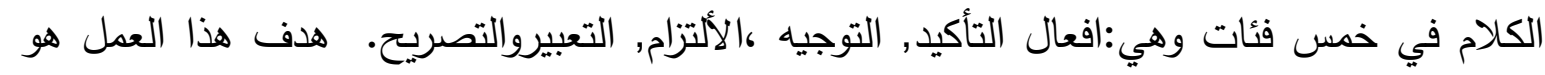
تحليل انواع الافعال الكلامي في نص المسرحيه "الجاموس الأمريكي" من كتابة ديفد ماميت. وسيكون

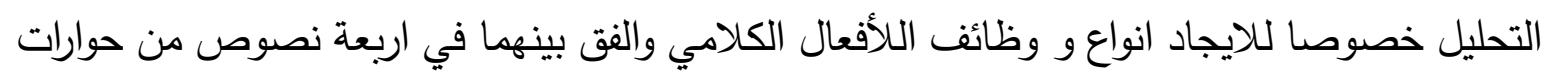

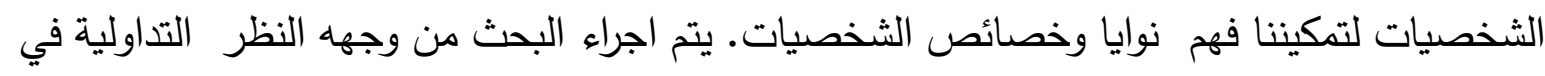
التحليل و التصنيف اعتمادا علي تصنيف سيرل (1969). 